\title{
GERMAN LITERATURE IN BRAZIL - WRITING AND TRANSLATING BETWEEN TWO WORLDS. THE WORKS OF HERBERT CARO AND ERNST FEDER AS WRITING- BETWEEN-WORLDS ${ }^{1}$
}

\author{
Sonja Arnold* \\ Bergische Universität Wuppertal
}

\begin{abstract}
German literature, like any other national literature, is usually constrained by territorial restrictions, the frontiers of either Germany or German-speaking countries. However, this very static point of view excludes spatial mobility and vectorial dynamism, which are the very basis of literature. Emigration to other countries, writing in different languages, or reading novels either in foreign languages or in translation have been starting points for literary production for centuries. These initial considerations are the basis for a new paradigm of literary historiography in a view of literature beyond national limits which includes spatial dynamism, cross-border movements and a concept of transatlantic literature beyond the notions of centre and periphery. In the case of Brazil this opens a whole field of investigation which is mainly unknown to traditional histories of German literature: literature that has been produced in Brazil by Germanspeaking emigrants of the nineteenth and twentieth century. My contribution will take into consideration two German writers in exile, Herbert Caro and Ernst Feder, and will employ a mode of distant reading to illustrate how these examples challenge concepts of traditional philology.
\end{abstract}

Keywords: German Literature in Brazil. Herbert Caro. Ernst Feder. TransArea Studies. Distant reading.

\footnotetext{
${ }^{1}$ My essay is based on a talk I delivered at the conference Translation in Exile, which took place in December 9-11, 2015 at the Vrije Universiteit Brussel.

* Sonja Mirjam Arnold: PhD in German literature (2012), MA in German Studies (2007), and BA in German Studies (2005) from the University of Freiburg, Germany. From 2011 to 2014 she worked as lecturer for the German Academic Exchange Service (DAAD) at the Federal University of Rio Grande do Sul in Porto Alegre, Brazil. She is Assistant Professor at the University of Wuppertal, Germany. Wuppertal, Nordrhein-Westfalen, Germany. E-mail: sarnold@uni-wuppertal.de
} 


\title{
A LITERATURA ALEMÃ NO BRASIL - ESCREVENDO E TRADUZINDO ENTRE DOIS MUNDOS. OS TRABALHOS DE HERBERT CARO E ERNST FEDER COMO ESCRITA- ENTRE-MUNDOS
}

\begin{abstract}
Resumo: A literatura alemã, como qualquer outra literatura nacional, é normalmente delimitada por restrições territoriais - as fronteiras ou da Alemanha ou de países de língua alemã. Porém, este ponto de vista estático exclui a mobilidade espacial e o dinamismo vetorial, que constituem a base da literatura. A emigração para outros países, a escrita em línguas diferentes ou a leitura de romances, quer em línguas estrangeiras quer em tradução, foram durante séculos pontos de partida para a produção literária. Estas considerações prévias estão na base de um novo paradigma de historiografia literária, que perspetiva a literatura para além dos limites nacionais e dá conta do dinamismo espacial, de movimentos transnacionais e de uma conceptualização de literatura transatlântica que vai além das noções de centro e periferia. No caso do Brasil, este paradigma abre um campo de pesquisa que é desconhecido sobretudo no âmbito das histórias tradicionais da literatura alemã: a literatura que foi produzida no Brasil por emigrantes de língua alemã nos séculos XIX e XX. O meu contributo terá em conta dois escritores alemães em exílio, Herbert Caro e Ernst Feder, e tirará partido de um modo de leitura distanciada para ilustrar como estes exemplos desafiam conceitos de filologia tradicional.
\end{abstract}

Palavras-chave: Literatura Alemã no Brasil. Herbert Caro. Ernst Feder. Estudos de Trans-Área. Leitura Distanciada

“Traduzir é conviver" (Caro 1985): Translating means coexisting. This is the title of an essay ${ }^{2}$ that the German-Jewish writer Herbert Caro published in Portuguese during his exile in Brazil. ${ }^{3}$ Caro not only wrote his essay in Portuguese and published it in a Brazilian journal, but was also quoting the famous Brazilian author Guimarães Rosa, who first wrote the above sentence. A certain conviviality is evident in the very act of translation, which

\footnotetext{
${ }^{2}$ The article is based on a lecture that he gave in Porto Alegre during an event on translation. It focuses on difficulties with translations by giving examples of his own work, especially the translation processes of the works of Thomas and Klaus Mann.

${ }^{3}$ The term "exile" could, in this case, be challenged since Caro considered Brazil home and never returned to Germany.
} 
cannot be seen as an isolated process projecting a to $\mathrm{b}$ but has to be regarded as a complex network of inter- and translingual processes. This is why TransArea Studies seek out a poetics of movement (Ette 1995, 27), from the spatial dimension to a history of movement (32). This history of movement is linked to emigration and translation processes and can be exemplified by taking German writers in Brazilian exile into consideration. Similar to other exile processes, a transnational (in this case a transatlantic) dimension confronts us here, as does a translingual dimension (in the mixing of German, Portuguese, and other languages, for example French in the aforementioned case of Caro $)^{4}$ and a trans-spatial ${ }^{5}$ dimension. On the one hand, being specific to the Brazilian context, these processes are based on a history of emigration that had already started in the early nineteenth century with the first German colony in São Leopoldo, Southern Brazil, in $1824 .{ }^{6}$ On the other hand, we can identify a double exile in the twentieth century, since the poets in exile during National Socialism were confronted with new restrictions in the 1930s by the so called Estado Novo under president Getúlio Vargas during which the use of the German language was forbidden. ${ }^{7}$ In my essay, I will be taking a closer look at two figures who worked as translators, journalists, literary critics, cultural mediators, and novelists: Herbert Caro and Ernst Feder. I will also be examining the spatial, cultural and lingual movements linked to their exile processes. My contention is that by considering these little known examples we can challenge concepts of national philology, literary historiography, and canonization,

\footnotetext{
${ }^{4}$ Many of the authors who found shelter in Brazil during National Socialism did not emigrate directly to Brazil but passed through several transit countries, as in the case of Karl Lieblich, who travelled to the US and Brazil via Switzerland, or in the case of Herbert Caro and Paul Frischauer, who both passed through France on their way to Brazil and the US, respectively.

${ }^{5}$ For the terms transnational, translingual and transspatial, see Ette (2005) and (2012b).

6 It is, however, possible to also differentiate the several emigration movements to Brazil during the nineteenth century in more detail (see Neumann [2005a] and [2005b] and Schulze/Rinke [2013], Schulze [2016]).
}

${ }^{7}$ Ulrich Becher published, for example, some of his works in French. 
and develop a concept of literature as ZwischenWeltenSchreiben [Writing-between-Worlds] (Ette 2005) beyond static criteria, which better fits a globalized world. The examples could, of course, be extended to nineteenth century German literature in Brazil (e.g. Wilhelm Rotermund or Clemens Brandenburger) or to the huge amount of German literature produced in Brazil in the first half of the twentieth century (Frank Arnau or Ricardo Sanders). ${ }^{8}$

National literature is a concept that has been extensively criticized in recent decades (Borsò 2003, Moretti 2000). Indeed, as early as 1827 Goethe announced "die Epoche der Weltliteratur" (Eckermann 1987, 198) [the era of world literature]. Taking a closer look at the entities of German and Brazilian literature, we find that the separation of the two national literatures cannot even be maintained at the very beginning of literary history. Going back to the first encounters of German and Brazilian culture, we are confronted with an exchange of several movements, especially in travel literature, starting with Hans Staden's Wahrhaftige Historia (Hans Staden's True History: An Account of Cannibal Captivity in Brazil, 1557), ${ }^{9}$ an autobiographical report of Staden's 1550 Spanish-led expedition to Brazil under Spanish conduct. The German soldier was captured by the Tupinambá tribe, who threatened to eat him, and finally managed to escape on a French ship and return to Germany, where he was able to write his story and describe the Tupinambá and their practice of cannibalism in more detail. Over the centuries, this report became increasingly famous, especially in Brazilian culture, and served as the basis for one of the most important manifestos of Brazilian modernism, the Cannibal Manifesto (Manifesto Antropófago) by Oswald de Andrade. In addition, there was a children's book by Monteiro Lobato, a comic book by Jô de Oliveira, a famous painting cycle of the story by the Brazilian painter Candido Portinari (Lustig

\footnotetext{
${ }^{8}$ For a detailed overview see Eckl 2010.

${ }^{9}$ The Brazilian translation was only published in 1941 under the title Hans Staden: Primeiros registros escritos e ilustrados sobre o Brasil e seus habitantes.
} 
2007), and two movies ${ }^{10}$ - we cannot unambiguously categorize any of these works as either German or Brazilian literature, as they consist of a mixture of intertextual, intercultural, intermedial, and interlingual elements.

These processes, which are obviously not only part of a modern and globalized world, can also be identified in the phenomena of emigration and exile. In the case of Germany and Brazil, we are confronted with several large emigration waves in the nineteenth century that led to the foundation of German colonies and the persistence of German songs, newspapers, and customs - some of which are still present today - especially in the southern Brazilian states of Rio Grande do Sul, Santa Catarina, and Paraná. A second large wave of German immigrants came to Brazil during the terror of the Nazis in the 1930s and 1940s, and the most famous immigrant among them was probably Stefan Zweig who spoke of Brazil as "Land der Zukunft" [Land of the Future] (1990). However, there were other writers, literary critics, and journalists who were less popular but whose destinies challenge concepts of national philology and also some definitions of world literature. ${ }^{11}$ Some continued to write in German but were no longer published, as is the case of Karl Lieblich. Others adapted to Portuguese language and became literary critics (Anatol Rosenfeld, Oskar Maria Carpeaux), journalists (Ernst Feder), translators (Herbet Caro), or writers (Paul Frischauer). Although all of these figures wrote in Portuguese, they remained connected to German language, culture, and history, and worked as cultural mediators. Much work has been done, especially by Brazilian researchers, on the historical background to this situation (Gertz 1989, Schulze 2016) and on the history of German-speaking literature in nineteenth-century Brazil (Neumann 2005) and during National Socialism (Eckl 2010, Eckl

\footnotetext{
${ }^{10}$ Como era gostoso o meu francês [How Tasty Was My Little Frenchman] (Nelson Pereira dos Santos, 1971) and Hans Staden (Luís Alberto Pereira, 1999).

${ }^{11}$ This includes all conceptions of world literature which consider the term from a quantitative (meaning the number of works which belong to a canon of world literature) or qualitative point of view, such as Hermann Hesse's Eine Bibliothek der Weltliteratur (1929).
} 
2013, Furtado Kestler 1993), including recent work by German academics. ${ }^{12}$ My contribution will focus on two characters who are less famous but whose work as authors, translators, and especially as cultural mediators helps us gain insights about the different exchange processes involved and could help us to consider German literature in Brazil as a product of ZwischenWeltenSchreiben.

Starting with Herbert Caro, it is difficult, however, to categorize both his profession and his cultural affiliations. He worked as a lawyer, bookseller, table tennis player, translator, and journalist, and had, at the same time, extensive knowledge of music, art, and politics. Caro was born in Berlin in 1906. When he was forbidden to work as a lawyer by the Nazis, he first emigrated to France - as many Jewish intellectuals did at the time - and then to the southern Brazilian city of Porto Alegre in 1934, when it was still relatively easy to obtain a letter of recommendation. Soon after his arrival to Brazil, he became involved in Jewish affairs by founding the Sociedade Israelita do Brasil (SIBRA) (Israeli Society of Brazil) in 1936, whose task - among others - was to help Jews and their families emigrate to Brazil and to support them in the first steps of integration in the new country. Subsequently, he worked at the Globo publishing company in Porto Alegre which was one of Brazil's most famous publishing houses during the 1940s, and which offered a mixture of southern Brazilian literature and world literature in Portuguese translation. During his time at Globo he developed a close bond to the Brazilian writer Érico Veríssimo, author of $O$ Tempo e o Vento [Time and the Wind], with whom he discussed translation and publication issues. This shows how deeply connected he was to Brazilian society and culture, from the very beginning of his exile. After acquiring sufficient knowledge of the Portuguese language, he started translating the works of Thomas Mann, Hermann Hesse, Elias Canetti, and many others (among them six Nobel Prize winners) into Brazilian Portuguese.

${ }^{12}$ See the project "Global Archives. Brasilien" by the Deutsches Literaturarchiv Marbach and the University of Cologne: http://www.global-archives.de/ueber-das-projekt/brasilien/ 
In addition, he contributed articles and essays to the Caderno de Sábado, a supplement of the journal Correio do Povo, where he wrote about German literature and culture and about contemporary problems of Brazilian society. However, his point of view was never unidirectional; he never merely translated or projected German culture onto Brazil. Instead, he was always looking for the link between both cultures, as can be seen from his article "A mãe brasileira de Thomas Mann" [Thomas Mann's Brazilian Mother] (Caro 1976), ${ }^{13}$ where he traced the Brazilian roots of Thomas Mann's mother Julia da Silva-Bruhns and discovered traces of these biographical roots in the fictional works of both Heinrich and Thomas Mann, especially in Heinrich Mann's Zwischen den Rassen and Thomas Mann's Buddenbrooks. His role as cultural bridge builder became more refined when he served as a co-founder of the Goethe-Institute library in Porto Alegre, where his wife Nina Caro worked as a German teacher, ${ }^{14}$ and which still exists to this day. This form of cultural exchange also operated in both directions, as can be seen in the many events he organized during his travels to Germany, such as several public presentations on Brazilian artists (for example, Aleijadinho and Candido Portinari) under the auspices of the German-Brazilian society (Deutsch-Brasilianische Gesellschaft) in the 1960s and 1970s.

All this information may seem to remain on a biographical level at first sight. However, I am convinced that it can sharpen our philological view when we consider these findings as a mode of distant reading, one that, according to Franco Moretti, "allows you to focus on units that are much smaller or much larger than the text" (57) and which can be applied to the works of Herbert Caro. When we try to extend the canon of world literature to the peripheries - and German literature in Brazil obviously belongs to the peripheries - we are quickly confronted with a problem of reading capacities. Moretti's idea is to replace the act of close

\footnotetext{
13 For a detailed analysis, see Kuschel (2013) and Soethe (2014).

14 For a more detailed study of Nina Caro's role, see Brumer/Gutfreind (2007).
} 
reading by a distant reading that allows us to focus much more on processes than on individual texts. This is one of the ways how we can examine translocal, transcultural, and translingual movements. The process of translation is one of such trans-movements which could help us to better understand the mechanisms that define German literature in Brazil. Let us therefore take a closer look at one of Caro's translation projects to comprehend the cultural crossings in his life and work. One of his major projects was the translation of Thomas Mann's novel Doktor Faustus into Portuguese, for which he received the national translation prize of the National Book Institute (Instituto Nacional do Livro) in 1984. First of all, we can highlight the fact that Caro translates into a language which is not his mother tongue and which he only learned during his exile. ${ }^{15}$ Secondly, he had to conduct major research in the field of music in order to translate the novel. As we learn in one of his letters, he used five different translations of Doktor Faustus (a not uncommon method among translators in Romance languages), and he tried to imitate the archaic style of the original by using "algumas expressões de até um século antes de Gil Vicente" [some expressions dating as far back as one century before the Portuguese writer Gil Vicente] ${ }^{16}$ (Chagall 2007, 14). However, he is aware of the fact that the French translation shows some problems, which were then incorporated into the Spanish translation, which had also used the French translation as a model. ${ }^{17}$ Caro had to cope with a large amount of background information that was necessary, including music theory, philosophy, and

15 Recent studies have shown that translations into a non-mother tongue are not necessarily linguistically and culturally deficient (see Pokorn 2005).

${ }^{16}$ Unless otherwise noted, all translations are my own.

17 “Para o 'Doutor Fausto' do Thomas Mann, usei nada menos de cinco, entre as quais a italiana era de longe a melhor. Atualmente, ao traduzir o 'Mefisto', de Klaus Mann, filho de Thomas Mann, tenho três em minha mesa, nas quais encontro os mesmos defeitos de sempre [...]" (Caro, 1985, 151) [To translate Thomas Mann's Doktor Faustus I used no less than five translations, of which the Italian was by far the best. At the moment, I am translating Mefisto by Klaus Mann, Thomas Mann's son, and I have three translations on the table in which I find the same deficiencies as always]. 
history. As a conclusion to his translation process he comments on the difficulties of working with these three languages: "As línguas não são triângulos simétricos" (Chagall 14) [Languages are not symmetrical triangles]. Considering the German source text, the French translation - which according to Caro omitted major parts of the German - and the target text in Portuguese as three sides of the triangle, the asymmetry stands out in phenomena such as the representation of different dialects and sociolects which led to major communication problems in Mann's novel Buddenbrooks.

In 1942, Caro had already translated Buddenbrooks and had even contacted Thomas Mann in order to ask him about a problem concerning the translation, namely how the question of dialects could be resolved. ${ }^{18}$ This method was not uncommon for Caro: he had already contacted Elias Canetti, and the two of them discussed major problems and decisions concerning the Portuguese translation in the letters they exchanged. In his letter to Mann Caro labels Mann's novel as "Weltliteratur" (world literature), using the concept as a quality criterion. However, the very attempt of translation and the blending of two cultural and linguistic horizons within this process suggest a more modern concept of world literature. In his letter to Thomas Mann, Caro makes use of both conceptions of world literature. He first points out the universal characteristics of Buddenbrooks, "mit ihrem tiefen menschlichen Gehalt" [with its deeply human content], but then mentions the reception in the Brazilian context:

Gewiss ist in diesem jungen und vorerst traditionslosen Land vieles fremd, was in diesem ungewöhnlich deutschen und norddeutschen Buch enthalten ist. Mancher Leser wird in ihm etwas von dem Reiz exotischer Fremdheit finden, den auf den Europäer Schilderungen fremder Länder

\footnotetext{
${ }^{18}$ Some of the characters in the novel speak Plattdeutsch (Low German), for example. Caro also mentions the dialogue between a Bavarian beer brewer and a lady from Northern Germany who are not able to understand each other. In the same letter, Caro asks for a photograph of Thomas Mann for his collection (Chagall, 2007, 71-73).
} 
ausüben. Andere werden vielleicht darüber hinaus imstande sein, die psychologische Tiefe dieses herrlichen Romans zu erfühlen. (Chagall, 2007, 72)

[Much of the content of this typically German or northern German book will be strange to this young country, which is devoid of tradition in the first place. Some readers will find the charm of exotic otherness in it, which descriptions of strange countries usually evoke in Europeans. Others will go beyond this and will be able to perceive the psychological profundity of this wonderful novel.]

The mentioned exoticism turns into a reciprocal experience and is no longer limited to a colonial perspective, but serves as perception filter for the other side too. Mann's novel is not only considered world literature because of its outstanding quality, but is also placed in the context of its international reception. It becomes world literature not by its intrinsic qualities but because of the mode of reading (Damrosch 2003) which places the novel in its process of reception. Two cultures are connected by the process of translation, and the translated work becomes world literature in this moment of cultural bridge building (Damrosch 2003). The German author confirms the different requirements for reception in his response when the two intellectuals discuss the best strategy to introduce Mann's work to the Brazilian market:

Zwar ist hier in den Vereinigten Staaten die Wirkung des "Magic Mountain" eine viel stärkere als die von "Buddenbrooks", aber ich bin mit Ihnen überzeugt, dass der bürgerliche Roman für ein südamerikanisches und literarisch vielleicht weniger gut vorbereitetes Publikum leichter zugänglich ist und besser zu meiner Einführung als Schriftsteller dienen kann. (Mann 1942) 
[Although the effect of the Magic Mountain is much greater than that of Buddenbrooks, I am convinced that this bourgeois novel is much more accessible to a South American public that has little experience with literature and can therefore better serve as my introduction as a writer.]

Caro seems to be quite aware of the several sides of world literature which also include market strategies as well as editorial and economic decisions.

In addition to his work as a translator, Caro worked as a journalist and published numerous articles in Portuguese in Brazilian journals and newspapers, among them Correio do Povo, Zero Hora, and Revista do Globo in Porto Alegre as well as Jornal de Letras (Rio de Janeiro), and Crônica Israelita (São Paulo). In these articles, he wrote about German music, Brazilian politics, German and Brazilian literature and art, as well as about general topics of contemporary Brazilian society. In his role as cultural mediator, he helped popularize the German writers Hermann Hesse and Elias Canetti, not only by translating their major works but also by placing his journalistic focus on them. ${ }^{19}$ In his columns in the newspaper Correio do Povo, he often pointed out the many differences between Europe and Brazil, making use of the dichotomy of the Old and the New World. However, when referring to Brazilians as "nosso povo" [our people], it is clear that his point of view has already become that of a Brazilian observer:

Um fenômeno que causa espanto ao europeu radicado no Brasil é a rapidez com que se modificam certos hábitos do nosso povo. No Velho Mundo um costume arraigado levaria séculos para ser abolido. Na nossa terra, porém, bastam às vêzes uns poucos anos para revolucionar por

19 "Adeus a Hermann Hesse" [Farewell to Hermann Hesse], Correio do Povo, August 14, 1962, and "Elias Canetti. Prêmio Nobel desconhecido" [Elias Canetti. Unknown Nobel Prize winner], Correio do Povo, October 25, 1981. 
completo o estilo de vida de vastas camadas da população. (Caro, 1960, 35)

[A phenomenon that causes astonishment to Europeans living in Brazil is the speed with which certain habits of our people change. In the Old World an entrenched custom would take centuries to be abolished. However, in our country a few years are sometimes enough to completely revolutionize the lifestyle of large sections of the population.]

Not only does Caro speak of Brazil as his country, he also points to the distinction between the Old World and the New World, and to the accelerating changes that he considers consequences of cultural contact. Herbert Caro is an example of several movements in different directions coming together and leading to a new cultural prosperity. By considering his translations, his letters, and his travels, we are able to trace the network of steps involved in a specific process of cultural contact, namely that of German literature in Brazil in the twentieth century. The life and work of Ernst Feder provides us with another example, albeit one with different consequences.

Born in 1881 in Berlin, Ernst Feder is probably best known for being the last person to have seen Stefan Zweig and his wife alive, on the evening before their suicide. ${ }^{20}$ In Germany, he worked as the chief editor of the newspaper Berliner Tagblatt, but emigrated because of the changing political climate, first to France and Switzerland in 1933, and then to Brazil in 1941. Although it was already quite difficult at that time to obtain a visa he succeeded in obtaining one and was allowed to write for Brazilian newspapers, for example for the Jornal do Brasil, only one year after his arrival to the new country - his success both with the visa and with his journalistic activities were probably due to his vast social networks,

${ }^{20}$ Recently, Zweig's exile in Brazil has been discussed in the movie Vor der Morgenröte by Josef Hader (2016). 
and to having the necessary connections. ${ }^{21}$ At the same time, he was writing about Brazilian topics for the Schweizer Nationalzeitung and the exile newspaper Aufbau, which was published in New York. Interestingly, he published some work in German in the Ijuí municipality in the southern Brazilian state of Rio Grande do Sul, where a huge German-speaking community lived and where he wrote short stories, poems, and a collection of essays on different topics for the Serra Post Kalender which had been published between 1922 and 1978. Feder wrote articles about the Amazons in Brazil ("Die Amazonen in Brasilien", Serra Post Kalender, 1955), about Lessing's notions of Brazil ("Lessing entdeckt Brasilien", Serra Post Kalender, 1952) and a report on the last days of his friend and colleague Stefan Zweig ("Begegnung in Petropolis. Die letzten Tage Stefan Zweigs", Serra Post Kalender, 1952).

In addition to his work as a cultural mediator via informative newspaper articles, he also published two works which are important in our context because of their role as generic and cultural in betweens. The first of these is his Brazilian diary, which starts with the day of his arrival in Rio de Janeiro (July 7, 1941) and which accompanies him during the process of acculturation in Brazil; this seems at first to be written in an autobiographical mode, but then instead turns out to be a collection of comments on global events and on the political and social circumstances both in Europe and in Brazil (Eckl 2012, 62). The second of these is the Diálogos dos Grandes do Mundo, which was first published in Portuguese in 1944 and could only be published in Germany in 1950, and which consists of fictitious meetings of important personalities across different cultures. Although Feder is today mainly known for being the last witness of Stefan Zweig's Brazilian exile and for the many articles he published on Zweig after the latter's death, he was obviously also a meticulous analyst of the experience in exile and the global political evolution seen from a transatlantic perspective.

${ }^{21}$ In this case the Brazilian ambassador whom he got to know in Paris and who helped him with a letter of recommendation (Eckl, 2010, $158 \mathrm{ff}$.). 
One of his other achievements was his essay Goethes Liebe $z$ u Brasilien [Goethe's Love for Brazil], in which he investigates Goethe's interest in Brazil and meticulously traces the author's interest and reception of Brazil. This essay was first published in the Serra Post Kalender in 1950, and serves as more evidence for Feder's immense work as cultural mediator. ${ }^{22}$ Goethe came to know Brazil primarily through his conversations with the botanist Carl Friedrich Philipp von Martius (1794-1868). This retrospective of the eighteenth century once again emphasizes that transcultural characteristics are not merely phenomena of the twentieth century, and that the many crossings and movements already existed centuries before. In a speech at the Teatro Serrador in Rio de Janeiro on August 29, 1949 (Goethe's two-hundredth birthday), Feder mentions the Brazilian plant Goethea, which was brought to Germany by Martius and Nees von Esenbeck after an expedition to Brazil, and which was named after the famous German writer, who also was an enthusiastic natural scientist. He concludes with the following: "Bei der Goethefeier von 1932 wurde im Jardim Botanico von Rio eine Goethea gepflanzt und der Wald von Itapeba zum Naturschutzgebiet erklärt" (Schneider 2013) [During the celebrations in honour of Goethe in 1932, a Goethea was planted in the Botanical Garden in Rio de Janeiro and the forest Itapeba was declared a conservation area]. It is interesting to take a closer look at the different movements and crossings which are involved in Feder's talk and which are exemplified by the above quotation. The first movement is that of botanical knowledge, which makes its way from Brazil to Germany in the eighteenth century. Afterwards the plant is named after a German poet, who then develops a keen interest for Brazil and is finally celebrated in Brazil and honoured

${ }^{22}$ Roquette Pinto mentions the following in the preface of the book: "Ich betrachte Ihre Arbeit, mein lieber Herr Feder, als einen weiteren guten Dienst, den Sie unserer Kultur erweisen, und der sich den vielen, die Sie seit etlichen Jahren den Brasilianern schenken, würdig zur Seite stellt" (Feder, 1950, preface) [I consider your work another good service for our culture, one that merits to being included among the many other services you have rendered to Brazil over the years]. 
by a German writer in Brazilian exile - a crossing of several movements and directions.

However, the involvement of Feder in Brazil was totally different from that of Herbert Caro, especially because he was able to publish in German. In spite of his large network of social connections he suffered difficulties with integration from the very beginning and did not speak of Brazil as a paradise-like locus amoenus. In 1949, he noted a poem in his diary: "Doch, Brasilien, dieses Eden, / Das an Bäumen wunderreich - / Wie nur kommt man - frag ich jeden - / hier auf einen grünen Zweig" (quoted after Eckl 2010, 248) [But Brazil, this Eden, / which is marvellously full of trees, / how could one be getting ahead?].

Feder is one of the many intellectuals in exile who returned to Germany after the Second World War, namely in 1958, when he was invited back by President Theodor Heuß. However, as was the case with many other people, the remigration was not successful. Feder did not succeed in becoming part of the literary canon of either Germany or Brazil. Apart from literary quality, his works, which seem to be forgotten so far primarily because they would not belong to one stable national literature, serve to store LebensWissen (knowledge of life) and ÜberlebensWissen (knowledge of how to survive) (Ette 2012b). It is only by tracing back the mentioned movements of the two characters and by applying a mode of distant reading that these works can be adequately evaluated. First of all, they do not belong to either of the national canons, German or Brazilian, and are therefore translocal. Secondly, they consist of an inseparable mixture of cultural influences and can be regarded as transcultural. And finally, many of the works I referred to were only written and published in one of the languages - German or Portuguese - often with words or sentences of the other language in it, which makes them translingual, therefore limiting their reception.

The case of German literature in Brazil, with the two exemplary biographies I have presented, shows the different processes that come together in cultural contact zones. They can be better understood 
by referring to TransArea Studies which take different movements as well as cultural and lingual parameters into consideration. We are, first of all, confronted with a translingual dimension: some authors, such as Herbert Caro, published in Portuguese, while others published in German or in both languages, as the example of Ernst Feder shows; during the Vargas regime publications in German were even forbidden. Translations were thus an important means of communication; they could be from or into the native language, or could even be self-translations. Third languages, especially French, often served to help in the translation process. In some regions, translation was not even necessary because German was a minority language, as in southern Brazil. Secondly, we are confronted with a translocal dimension since several processes of migration and of remigration can be seen. When we try to trace this literature today, we will barely find reference to it in German or Brazilian literary histories. There are still German-language documents in Brazilian archives so that we can speak of Literaturen ohne festen Wohnsitz (Literatures-without-a-Fixed-Abode). ${ }^{23}$ Finally, the transcultural dimension comes in when we consider the intellectuals' role as cultural. As in the case of the Goethea plant, it becomes obvious that we are not talking about singular movements from a to $b$ but of a whole network which shows the form of a Möbius strip, where it is impossible to detect beginning and ending or to distinguish between inside and outside. Untangling the different movements involved in these processes can help us not so much to (re)define or categorize this kind of literature but to better understand the structure of different examples of world literature with their different facets.

${ }^{23}$ For the use of this concept for German literature in Brazil, see also Neumann (2014). 


\section{References}

Asmus, Sylvia, and Marlen Eckl (Ed.). “...mehr vorwärts als rückwärts schauen..."/,olhando mais para frente do que para trás.” Das deutschsprachige Exil in Brasilien 1933-1945. O exílio de língua alemã no Brasil 1933-1945. Berlin: Hentrich \& Hentrich, 2013.

Borsò, Vittoria. "Europäische Literaturen versus Weltliteratur. Zur Zukunft von Nationalliteratur." Jahrbuch der Heinrich-Heine-Universität Düsseldorf (2003): 233-50.

Brumer, Anita, and Ieda Gutfreind. "Nina Caro, uma mulher de destaque." Revista Contingentia 2 (2007): 36-43.

Caro, Herbert. “Traduzir é conviver.” Trad. \& Comun. (1985): 149-154.

. “A mãe brasileira de Thomas Mann”. Correio do Povo. 1976.

. Balcão da Livraria. Rio de Janeiro: Ministério da Educação e Cultura, Serviço [sic] de Documentação, 1960.

Damrosch, David. What Is World Literature? Princeton: Princeton University Press, 2003.

Eckermann, Johann Peter. Gespräche mit Goethe in den letzten Jahren seines Lebens. Ed. Regine Otto. $4^{\text {th }}$ ed. Berlin: Beck, 1987.

Eckl, Marlen. „Das Paradies ist überall verloren“. Das Brasilienbild von Flüchtlingen des Nationalsozialismus. Frankfurt/Main: Iberoamericana, 2010.

Eckl, Marlen. “"A flor do exílio» - A amizade de Stefan Zweig e Ernst Feder vista a partir do Diário Brasileiro de Feder." WebMosaica. Revista do Instituto Cultural Judaico Marc Chagall 4.2 (2012): 61-70.

Eckl, Marlen. "Das geistige Band zwischen der Alten und Neuen Welt - Publizisten, Schriftsteller, Übersetzer und Theaterschaffende als Kulturvermittler.” “...mehr 
vorwärts als rückwärts schauen..."/ "olhando mais para frete do que para trás." Das deutschsprachige Exil in Brasilien 1933-1945. O exílio de língua alemã no Brasil 1933-1945. Ed. Sylvia Asmus, and Marlen Eckl. Berlin: Hentrich \& Hentrich (2013): 10-33.

Ette, Ottmar. ZwischenWeltenSchreiben. Literaturen ohne festen Wohnsitz. Berlin: Kadmos, 2005.

. TransArea. Eine literarische Globalisierungsgeschichte. Berlin: de Gruyter, 2012a.

$\frac{}{2012 b .}$. Konvivenz - Literatur und Leben nach dem Paradies. Berlin: Kadmos,

Feder, Ernst. Goethes Liebe zu Brasilien. Mit vier Bildern und einem Vorwort von Professor Roquette Pinto. Ijuí: Ulrich Löw, 1950.

Furtado Kestler, Izabela Maria. Die Exilliteratur und das Exil der deutschsprachigen Schriftsteller und Publizisten in Brasilien. Frankfurt/Main: Peter Lang, 1992.

Gertz, René. Memórias de um Imigrante Anarquista. Porto Alegre: Editora da UFRGS, 1989.

Hesse, Hermann. Eine Bibliothek der Weltliteratur. Leipzig: Reclam, 1929.

Instituto Cultural Judaico Marc Chagall: "Documentos do Arquivo Herbert Caro. Instituto Cultural Judaico Marc Chagall em Porto Alegre." Revista Contingentia 2 (2007): 57-74.

Kuschel, Karl Joseph, Frido Mann, and Paulo Soethe. Terra mátria. A família de Thomas Mann e o Brasil. Rio de Janeiro: Civilização brasileira, 2013.

Lustig, Wolf. "A Junesche been ermiuramme. Die Umsetzung von Hans Stadens 'Wahrhaftige[r] Historie der wilden, nackten grimmigen Menschenfresser-Leute' als Re-Tupierung der europäisch-brasilianischen Begegnung." Entdeckung, Eroberung, Inszenierung : filmische Versionen der Kolonialgeschichte Lateinamerikas und Afrikas. Ed. Ute Fendler. München: Meidenbauer (2007): 77-100. 
Mann, Thomas. "Letter to Herbert Caro, 05 May." Instituto Cultural Judaico Marc Chagall, Porto Alegre, 1942.

Moretti, Franco. "Conjectures on World Literature." New Left Review 1 (2000): 54-68.

Müller, Gesine. Die koloniale Karibik. Transferprozesse in hispanophonen und frankophonen Literaturen. Berlin: de Gruyter, 2012.

Neumann, Gerson Roberto. "Brasilien ist nicht weit von hier!" Die Thematik der deutschen Auswanderung nach Brasilien in der deutschen Literatur im 19. Jahrhundert (1800-1871). Frankfurt/Main: Peter Lang, 2005a.

Neumann, Gerson Roberto. "A temática da emigração alemã para o Brasil em obras de três autores da literatura alemã do século XIX: Amalia Schoppe, Friedrich Gerstäcker e Joseph Hörmeyer." MÉTIS: História \& Cultura 4.8 (2005b): 37-59.

Neumann, Gerson. "Uma literatura entre-lugares. O caso da literatura alemã produzida no Brasil no século XIX.” Projekt (Curitiba) 52 (2014): 11-16.

Pokorn, Nike K. Challenging the Traditional Axioms. Translations into a nonmother tongue. Amsterdam/Philadelphia: John Benjamins Publishing, 2005.

Schneider, Sylk. "Goethes Gedankenreise in die Palmenheine Südamerikas". Available at < http://www.goethe.de/wis/bib/prj/hmb/the/159/de10431966.htm> .

Schulze, Frederik. Auswanderung als nationalistisches Projekt. ,Deutschtum ' und Kolonialdiskurse im südlichen Brasilien (1824-1941). Köln: Böhlau, 2016.

Schulze, Frederik and Stefan Rinke. Kleine Geschichte Brasiliens. München: Beck, 2013.

Soethe, Paulo. „Eine Begegnung in Denver: Thomas Mann, Érico Veríssimo - und Herbert Caro als Überbringer. "Verlag Macht Weltliteratur. Lateinamerikanischdeutsche Kulturtransfers zwischen internationalem Literaturbetrieb und Übersetzungspolitik. Ed. Gesine Müller. Frankfurt: Tranvia (2014) 133-145. 
Staden, Hans, Franz Obermeier, Joachim Tiemann, and Guiomar de Carvalho Franco: „Warhaftige Historia“: zwei Reisen nach Brasilien (1548 - 1555). Kritische Ausgabe. Kiel: Westensee, 2007.

Zweig, Stefan. Brasilien. Ein Land der Zukunft. Frankfurt/Main: S. Fischer, 1990.

Recebido em: 23/06/2016

Aceito em: 10/10/2016

Publicado em janeiro de 2017 